\title{
Transformation of Cells by Photoinactivated Murine Gamma-Herpesvirus 68 during Nonproductive and Quiescent Infection
}

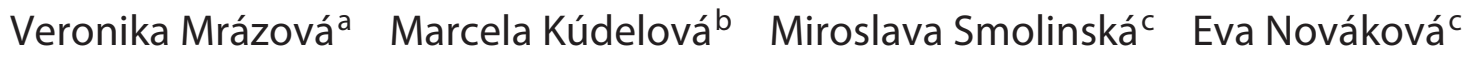 \\ Miroslava Šupolíkovác Michaela Vrbováb František Golais ${ }^{c}$ \\ ${ }^{a}$ St. Elisabeth Cancer Institute, ${ }^{\mathrm{b}}$ Institute of Virology, Biomedical Research Center, Slovak Academy of Science, and \\ 'Department of Microbiology and Virology, Faculty of Natural Science, Comenius University, Bratislava, Slovakia
}

\section{Keywords}

Murine herpesvirus $68 \cdot$ Photoinactivation $\cdot$ Cell

transformation · Quiescent infection

\begin{abstract}
Infection of human MRC- 5 cells and mouse NIH-3T3 cells with a murine gamma-herpesvirus (MuHV-4 strain 68; MHV-68) photoinactivated by visible light in the presence of methylene blue $(\mathrm{MB})$ resulted in nonproductive infection and the appearance of morphologically transformed cells. Two stably transformed cell lines were derived from both of these cell types and were confirmed to contain both viral DNA and antigen. Next, a quiescent MHV-68 infection in MRC-5 and NIH$3 \mathrm{~T} 3$ cells was established after cultivation at $41^{\circ} \mathrm{C}$ in the presence of phosphonoacetic acid. Following the exposure of quiescently infected cells to visible light for $120 \mathrm{~s}$ (5 times daily for 6 days) in the presence of MB, both MRC- 5 and $\mathrm{NIH}$ $3 \mathrm{~T} 3$ cells were observed to acquire transformed phenotypes. The cytopathic effect was observed in cells after 4-5 passages, after which the cells degenerated. However, when human interferon (IFN)- $\alpha$ and mouse IFN- $\beta$ were added to the media of quiescently infected MRC- 5 and NIH-3T3 cells during the photoinactivating procedure, 2 stable transformed cell lines
\end{abstract}

(c) 2017 S. Karger AG, Basel containing both viral DNA and the antigen were obtained and resembled those attained following nonproductive infection with photoinactivated virus.

(C) 2017 S. Karger AG, Basel

\section{Introduction}

Photodynamic therapy (PDT) using light-sensitive compounds (photosensitizers), such as neutral red (NR), methylene blue (MB), proflavine, and others [1], which become toxic to targeted bacteria, fungi, or cancer cells upon exposure to visible light, has recently found wide application [2,3]. Similarly, viruses treated with photosensitizers can be rendered sensitive to visible light [4-6].

Photoinactivation of herpesviruses was intensively studied in the 1970s and the 1980s. Yen and Simon [7] observed that herpes simplex virus type 1 (HSV-1) became sensitive to light when treated with NR, and similar results were obtained by Schnipper et al. [8] and Badylak et al. [9] with pseudorabies virus, using MB, light, and electricity. Müller-Breitkreuz and Mohr [10] observed that $\mathrm{MB}$ and light treatment of herpesviruses gives rise to DNA damage and blocks virus replication. Kelleher and

František Golais

Department of Microbiology and Virology Faculty of Natural Science, Comenius University Ilkovičová 6, SK-84215 Bratislava (Slovakia) E-Mail franz_golais@yahoo.de 
Varani [11] demonstrated that NR caused reduction in the reactivation rate of $\mathrm{HSV}-2$ from quiescent infection. Recently, Latief et al. [12] demonstrated that PDT is effective in eliminating acyclovir-resistant as well as nonresistant strains of HSV-1 from infected cells in vitro without harmful effects on host cells. On the other hand, attempts to use photoinactivation for the treatment of herpetic lesions have given contradictory results. Felber et al. [13] were successful in curing recurrent HSV infection using several heterocyclic dyes and fluorescent light. In contrast, Roome et al. [14] concluded that photoinactivation with NR was not effective in the treatment of acute genital herpes infections. Similarly, Meyers et al. $[15,16]$ failed to demonstrate the photodynamic inactivation of recurrent herpetic infection using NR. Recently, Marotti et al. [17, 18] were successful in the use of PDT as a treatment for herpes labialis, and similar results were obtained by Tardivo et al. [19] and Ramalho et al. [20]. However, some studies have demonstrated that photoinactivation of HSV-1 and HSV-2 in the presence of NR resulted in transformation of the cells in vitro, and thus PDT may be potentially oncogenic [21-23]. Wainwright [4] believes that the modern approach to phototherapy as well as the use of new, thoroughly tested photosensitizers could help eliminate potential side effects such as the transformation of cells. Recently, transformation of MRC-5 and NIH-3T3 cells in vitro was demonstrated after infection with UV-irradiated alpha-herpesviruses, HSV-1 and HSV-2 [24-26]. Moreover, UV-irradiated murine gamma-herpesvirus 68 (MHV-68) enabled the transformation of human and mouse dermal fibroblast cells in which the disappearance of actin bundles was demonstrated [27].

In this study, for the first time, infection with MHV-68 photoinactivated by visible light in the presence of $\mathrm{MB}$ was demonstrated. MHV-68 - a natural pathogen of murid rodents - is a member of the Gammaherpesvirinae subfamily. This subfamily also includes the Epstein-Barr virus (EBV) and Kaposi sarcoma-associated herpesvirus (HHV-8) that infect humans and are oncogenic. Because MHV-68 is similar to both EBV and HHV-68, in that infected mice develop lymphoproliferative disease and display high-grade lymphomas a long time after in vivo infection, it is currently used as an animal model for the study of human gamma-herpesvirus pathogenesis and oncogenesis [28-31]. Unlike EBV and HHV-8, MHV-68 replicates in various cultured cells, reaching high titers, and displaying cytopathic effect (CPE) and plaques in the agar overlay assay, thus having a greater resemblance to alpha-herpesviruses than gamma-herpesviruses $[29,32$,
33]. Here, we studied the effect of photoinactivation on cells infected with treated MHV-68 and on cells quiescently infected with nontreated virus. We evaluated the transformation of human embryonic lung cells (MRC-5) and mouse fibroblast cells (NIH-3T3): (i) following infection with MHV-68 photoinactivated by exposure to visible light in the presence of $\mathrm{MB}$, and (ii) by photoinactivation induced in cells quiescently infected with MHV-68, thereby modifying the experiments performed by Kelleher and Varani [11] and by Colberg-Poley et al. [34].

\section{Materials and Methods}

Virus

We used MHV-68 clone $\mathrm{f} 2.6$ originated from the isolate of MHV-68 kindly provided by Prof. Mistríková (Comenius University, Bratislava, Slovakia) that was plaque-purified twice, as described previously [35]. The virus was propagated and titrated using baby hamster kidney fibroblast (BHK-21) cells derived from the kidneys of 1-day-old hamsters (ATCC CCL-10), as described previously [36].

\section{Cells}

The following cells were used: MRC-5 cells (ATCC CCL-171), a human diploid cell culture established from the normal lung tissue of a 14-week-old male fetus; NIH-3T3 cells, mouse fibroblasts obtained from Swiss albino mouse embryo tissue. The cells were cultivated in DMEM (Dulbecco's modified Eagle's medium) supplemented with $7 \%$ fetal bovine serum, $1 \%$ L-glutamine, and $1 \%$ prostate-specific antigen, and incubated at $37^{\circ} \mathrm{C}$ in a humidified $5 \% \mathrm{CO}_{2}$ atmosphere.

Photoinactivation of MHV-68 and the Infection of Cells

$\mathrm{MB}$ (Loba Feinchemie GmbH, Austria) diluted in phosphatebuffered saline was added to $1 \mathrm{~mL}$ of MHV-68 suspensions containing $1 \times 10^{6} \mathrm{PFU}$ in $6-\mathrm{cm}$ plastic Petri dishes to obtain a final concentration of $0.1 \mathrm{nmol} / \mathrm{L}$. Virus suspensions were then exposed to LED light at a distance of $5 \mathrm{~cm}$ at $37^{\circ} \mathrm{C}$. A monochromatic LED red light system (homemade device, $\lambda_{\max }=650 \mathrm{~nm}, 15.0 \mathrm{Jcm}^{-2}$ ) was used for the experiments. The emission spectrum of the light system was measured at a high resolution of the Red Tide USB650 Fiber Optic Spectrometer (Ocean Optics, USA). The samples of photoinactivated virus taken at 30-s intervals from 30 to $120 \mathrm{~s}$ were used to infect BHK-21 cells. After 1 day of culture, the titer of photoinactivated virus in the culture media was evaluated as previously described [37] and compared to the controls. The plaques were counted and the virus titers were expressed as PFU/mL. Data obtained from the plaque assays performed in triplicate were expressed as the mean \pm SD. Appropriate samples of photoinactivated MHV-68 were diluted 10 times and used to infect 24 -h-old monolayers of MRC-5 or NIH-3T3 cells grown in 96-well plates. Infected cells were observed daily for the appearance of CPE or morphological changes and later passaged. Untreated virus diluted in the same manner served as a negative control. Virus suspensions added to cells containing the same MB concentrations but kept in the dark served as an additional control.
62

Intervirology 2017;60:61-68

DOI: $10.1159 / 000479373$
Mrázová/Kúdelová/Smolinská/Nováková/ Šupolíková/Vrbová/Golais 


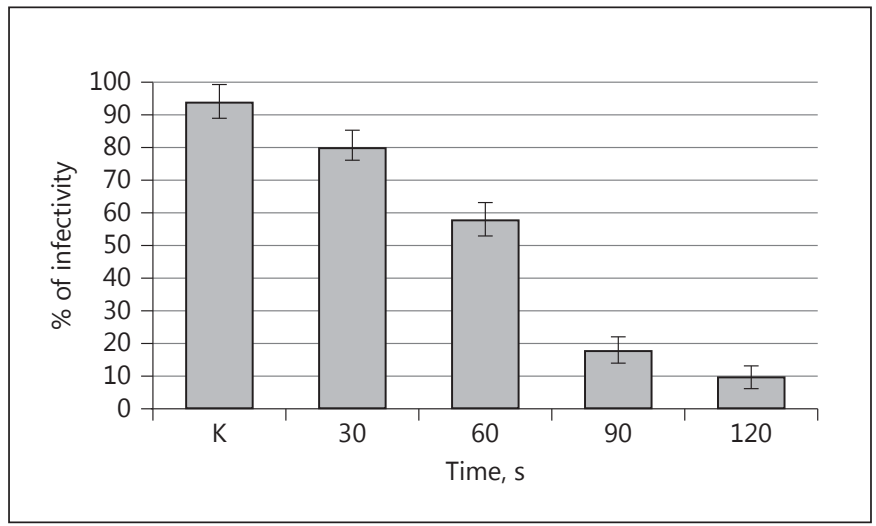

Fig. 1. The reduction of infectivity in BHK-21 cells of MHV-68 photoinactivated by exposure to visible light at different time intervals in the presence of $\mathrm{MB}$ evaluated by plaque assay. Data are expressed as the mean \pm SD from experiments performed in triplicate. $\mathrm{K}$, control BHK cells containing $\mathrm{MB}$ but infected with nonphotoinactivated MHV-68 (kept in the dark).

\section{Morphological and Cytological Examination of Cells}

Cells cultivated in 6-cm plastic Petri dishes were fixed with 50\% methanol for $10 \mathrm{~min}$, followed by $100 \%$ methanol for $10 \mathrm{~min}$, and stained using the Giemsa-Romanowsky method.

\section{Establishment of Quiescent Infection of Cells with Untreated} MHV-68 and Photoinactivation

MRC-5 and NIH-3T3 cells were grown in 24-well plates for 48 $\mathrm{h}$ until a confluent cell monolayer was formed. The cultivating medium was then replaced by that containing PAA (an inhibitor of DNA synthesis; Sigma) at a concentration of $200 \mu \mathrm{g} / \mathrm{mL}$ and the cells were cultured at $41^{\circ} \mathrm{C}$. Following $24 \mathrm{~h}$ of cultivation, cells were infected with MHV-68 at a multiplicity of infection of $0.01 \mathrm{PFU} /$ $\mathrm{mL}$ and cultivated for the next $24 \mathrm{~h}$ at $41^{\circ} \mathrm{C}$ in the presence of PAA. Thereafter, the medium was replaced with a medium without PAA and with $2 \%$ inactivated fetal bovine serum and $0.1 \mathrm{nmol} / \mathrm{L}$ of $\mathrm{MB}$. The cells were then cultivated at a temperature shifted down to $37^{\circ} \mathrm{C}$. Before the photoinactivation of MRC-5 and NIH-3T3 cells quiescently infected with MHV-68, human leucocyte interferon (IFN)- $\alpha$ and mouse IFN- $\beta$ (PBL Interferon Source) were added to obtain a final concentration $200 \mathrm{U} / \mathrm{mL}$. Next, the cells were exposed to LED light for $120 \mathrm{~s} 5$ times daily (at 2-h intervals) for 6 days, whereas they remained intact during the night. Cells were then trypsinized and thereafter passaged using the DMEM medium without MB and IFN. MRC-5 and NIH-3T3 cells cultured in the presence of relevant IFNs in the medium without MB and those cultured without IFNs and MB in the medium served as controls.

\section{Polymerase Chain Reaction}

DNA from transformed cell lines was isolated and screened for the presence of MHV-68 DNA by standard nested polymerase chain reaction (PCR) targeting the ORF 50 gene of MHV-68, as previously described by Kúdelová et al. [37]. The sequences of forward and reverse primers amplifying a 382-bp-long nested PCR product were as follows: ORF50/F1: $5^{\prime}$-AACTGGAACTCTTCTGTGGC-3', ORF50/R1: 5'-GGCCGCAGACATTTAATGAC-3', and ORF50/F2: 5'-CCCCAATGGTTCATAAGTGG-3', ORF50/ R2: $5^{\prime}$-ATCAGCACGCCATCAACATC-3'. DNA of MHV-68 $\mathrm{BAC}$ served as the positive control. All of the PCR work performed complied with generally known strict protocols to cross-contamination controls, such as pipetting the template in a separated PCR box and room, and using a PCR mixture without a template as a negative control. The nested PCR products were resolved on $1.5 \%$ agarose gels and samples yielding PCR products of the expected size were evaluated.

\section{Immunofluorescence}

Indirect immunofluorescence assay was performed. Coverslip cultures of MRC-5 and NIH-3T3 cells were fixed in 4\% paraformaldehyde and stained with rabbit hyperimmune anti-MHV-68 serum and Protein G Alexa Fluor 488 (Invitrogen). Nuclei were labeled with DAPI (Invitrogen).

\section{Results}

\section{Infection of MRC-5 and NIH-3T3 Cells with}

Photoinactivated MHV-68

To evaluate the effect of photoinactivation on MHV68 , we exposed virus samples of a titer of approximately $1 \times 10^{6} \mathrm{PFU} / \mathrm{mL}$ to visible light in the presence of $\mathrm{MB}$. The infectivity of MHV-68 photoinactivated at various time intervals from 30 to $120 \mathrm{~s}$ was determined using BHK-21 cells. We observed that the titer of photoinactivated virus continuously decreased with increasing light exposure time. As shown in Figure 1, an exposure of 30 s caused an approximate $20 \%$ decrease in virus infectivity, while it was reduced to approximately $10 \%$ after $120 \mathrm{~s}$ of photoinactivation. When MRC-5 and NIH-3T3 cells were infected with virus photoinactivated for 90 and $120 \mathrm{~s}$ and cultivated as shown in Figure 2, the morphology of both cell types changed, resembling a transformed phenotype. We observed that MRC-5 as well as NIH-3T3 cells maintained such morphological changes for the next 4-5 passages (approx. 30 days) and then entered crisis. They ceased to form a confluent monolayer and detached from the bottom. However, after additional cultivation (10-15 days), a few foci of morphologically transformed cells with a marked "crisscross pattern of growth" characteristic appeared in approximately $20 \%$ of the NIH-3T3 cells (Fig. 3a) as well as in the MRC-5 cells (data not shown). These cells remained transformed throughout the following passages and allowed us to derive a novel stable transformed cell line from NIH-3T3 (Fig. 3b) as well as MRC5 cells (data not shown). Both cell lines were then evaluated for the presence of viral antigen and DNA. MHV-68 antigen was clearly visible throughout the cytoplasm of the transformed cells of both cell lines. Transformation of 
Fig. 2. Passaging of MRC-5 and NIH-3T3 cells infected with photoinactivated MHV68 .
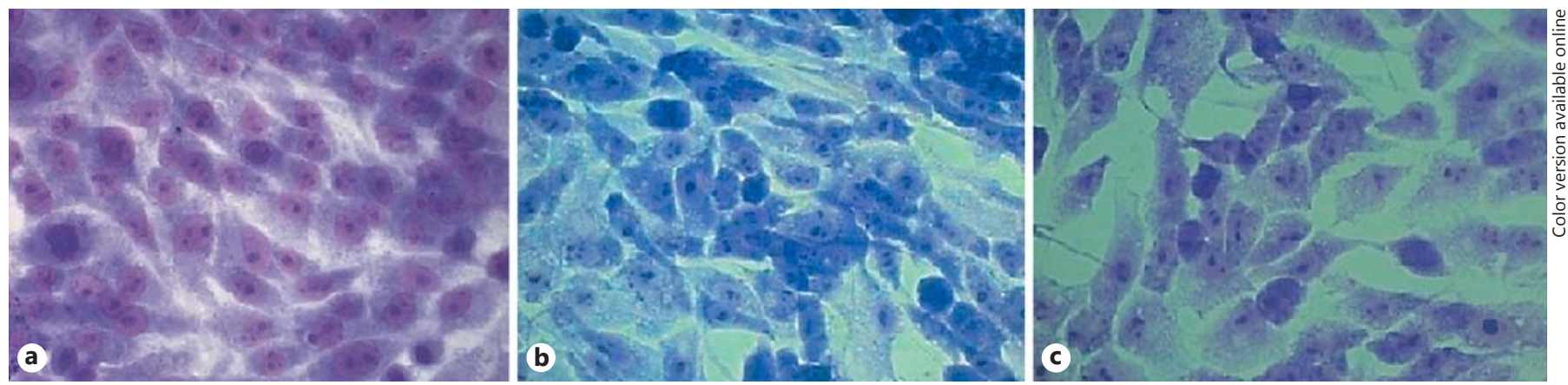

Fig. 3. Transformed NIH-3T3 cells derived from cells infected with photoinactivated MHV-68. Cells after crisis (a), transformed cells after the 3 rd passage (b), and control NIH-3T3 cells (c). Original magnification, $\times 50$.

Fig. 4. Transformed MRC-5 cells derived from cells infected with photoinactivated MHV-68 stained with rabbit hyperimmune anti-MHV-68 serum and Protein G Alexa Fluor 488, detected by the immunofluorescence method. Transformed cells after the 3rd passage (a) and control MRC5 cells (b). Original magnification, $\times 50$.
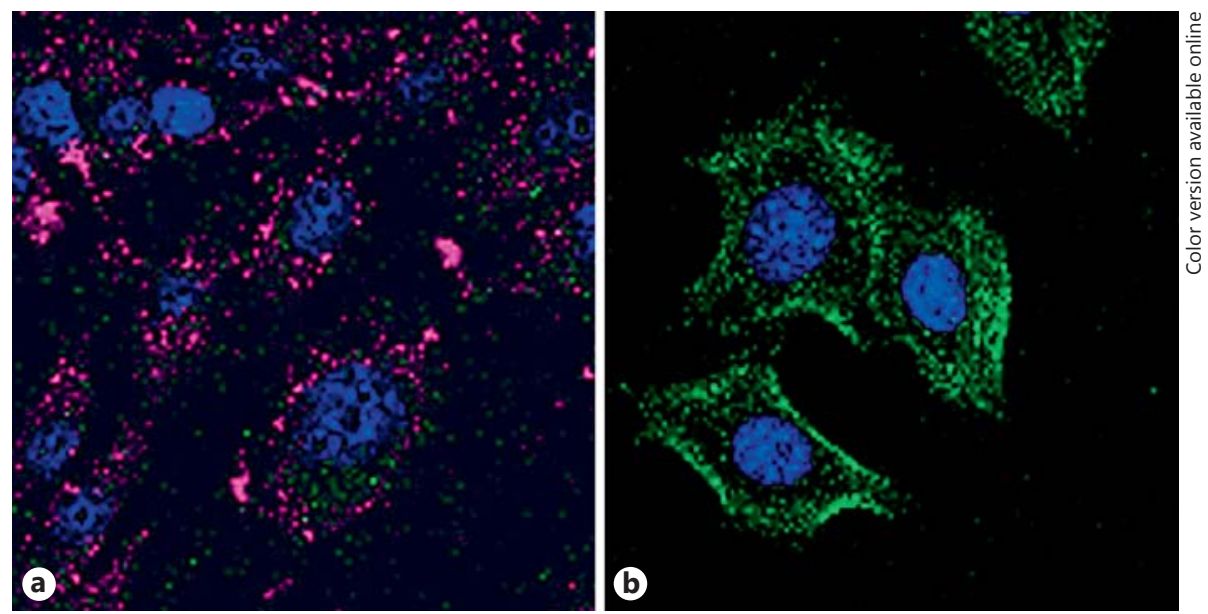


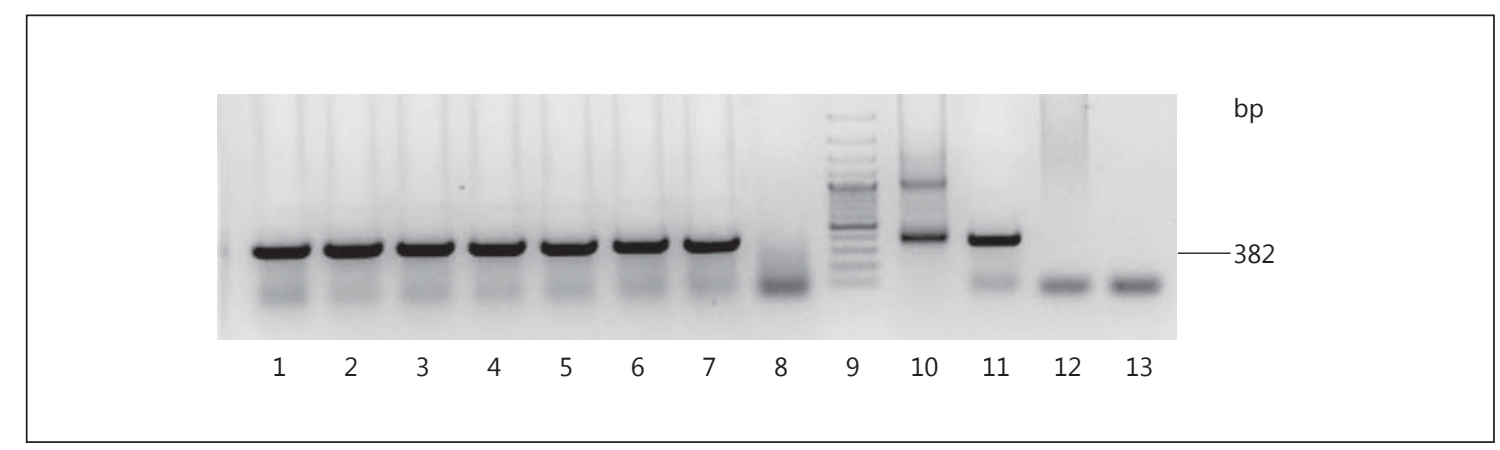

Fig. 5. PCR detection of MHV-68 DNA in transformed MRC-5 and NIH-3T3 cells. DNA extracted from cells derived from cells infected with photoinactivated MHV-68. Lanes 1-3: MRC-5 cells after the 3 rd, 7th, and 10th passages; lanes 4-5: NIH-3T3 cells after the $3 \mathrm{rd}$ and 8 th passages. DNA extracted from cells derived from quiescently infected MHV-68 cells photoinactivated in the presence of human $\alpha$-IFN. Lanes 6-7: NIH-3T3 and MRC-5 cells after the 7th passage; lane 8: noninfected MRC-5 cells; lane 9: 100-bp ladder (Fermentas); lane 10: MHV-68 BAC DNA (nested PCR; positive control); lane 11: MHV-68 BAC DNA (1-step PCR with nested primers; positive control); lane 12: no template (nested PCR; negative control); lane 13: no template (1-step PCR with nested primers; negative control).

Fig. 6. Transformed MRC-5 cells derived from cells quiescently infected with MHV68 that were photoinactivated in the presence of human leucocyte IFN- $\alpha$. Transformed cells after the 5th passage (a) and control MRC-5 cells (b). Original magnification, $\times 50$.
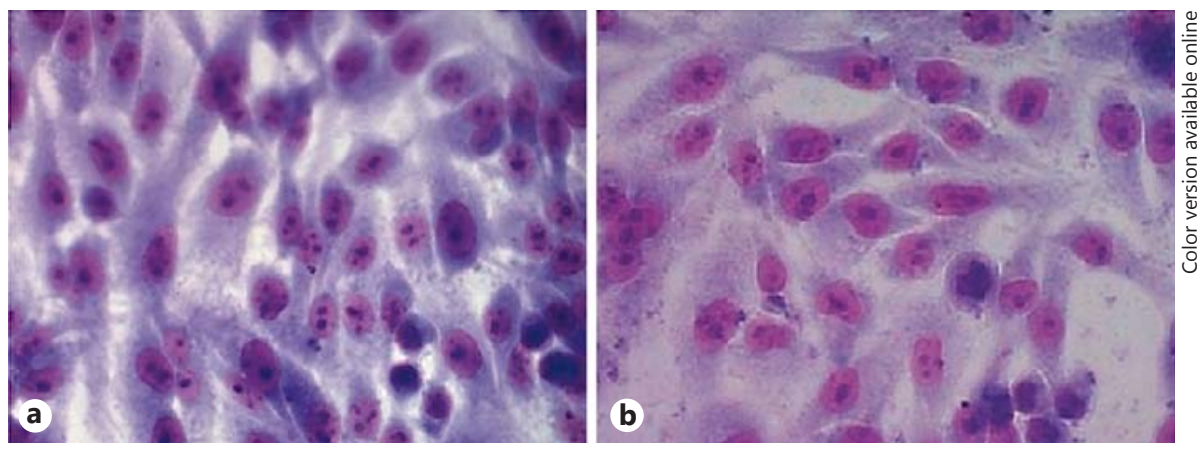

MRC-5 cells after the 3rd passage (Fig. 4a) and of NIH$3 \mathrm{~T} 3$ cells after the 4 th passage (data not shown) induced by infection with photoinactivated MHV-68 was observed to be associated with visible disintegration of actin filaments and the presence of virus antigens, as detected by immunofluorescence analysis. Using PCR, the presence of MHV-68 DNA was detected in transformed MRC-5 cells after the $3 \mathrm{rd}, 7$ th, and 10th passages (Fig. 5, lanes 1-3), and in transformed NIH-3T3 cells after and the 3rd and 8th passages (Fig. 5, lanes 4-5).

\section{Photoinactivation of Cells Quiescently Infected with MHV-68}

In the following experiments, we investigated the effect of photoinactivation on cells that were "latently" or quiescently infected with nontreated MHV-68. We established a quiescent infection of MRC-5 and NIH-3T3 cells with MHV-68 following a shift in incubation tempera- ture of cultures from 41 to $37^{\circ} \mathrm{C}$ and PAA removal, and demonstrated that no CPE appeared and no infectious virus was detected during the subsequent 4 - to 5-day period of culture (data not shown). The CPE subsequently appeared after 6 days of culture when the cells had degenerated. However, when MB was added to the medium of quiescently infected cells and they were exposed to visible light, morphological changes appeared after 5 days of culture resembling those of the cells infected with photoinactivated virus (as shown in Fig. 3b). However, it was not possible to passage these cells more than 4-5 times before they died. When human IFN- $\alpha$ and mouse IFN- $\beta$ was added to the medium of quiescently infected MRC- 5 and NIH-3T3 cells before the photoinactivation procedure, morphological changes in cells resembling the transformed phenotype were much more pronounced compared to those in the cells cultured without IFN. Cells of both types could be subsequently passaged without the 
appearance of $\mathrm{CPE}$ and infectious virus in the medium. Subsequent serial passaging resulted in stable transformed MRC- 5 cells (Fig. 6a) and NIH-3T3 cells (data not shown), respectively. We demonstrated that none of the IFNs had an effect on the morphology of quiescently infected cells untreated by photoinactivation. Finally, we confirmed by PCR that, similar to the cells obtained after infection with photoinactivated virus, both NIH-3T3 and MRC- 5 cells contained MHV-68 DNA after the 7th passage (Fig. 4, lanes 6 and 7).

\section{Discussion}

In the 1970s, photoinactivation following exposure to $\mathrm{NR}$ and $\mathrm{MB}$ was reported to be effective in the treatment of recurrent herpes simplex infections in humans [13, 38]. Thereafter, several works pointed at a transforming, and thus potentially oncogenic potential of herpes simplex viruses photoinactivated in the presence of NR [22, $23,38]$. However, it was demonstrated in some cases that NR was not effective in the treatment of herpetic lesions [14-16]. In our previous study, we demonstrated that UV-inactivated MHV-68 can transform cells in vitro [27], thus resembling the transforming ability of several UV-inactivated herpesviruses belonging to the subfamily Alphaherpesvirinae, such as HSV1, HSV2, and EHV [24$26,39]$. Recent studies have reported that normal cell lines such as MRC-5 and NIH-3T3 (used in this study) cultured in the presence of $\mathrm{MB}$ acquired a transformed phenotype accompanied by the presence of virus when they were infected with photoinactivated nonsyn strains (K17 and Kupka) but not syn strains (HSZP) of HSV-1 [40].

No photoinactivation experiments on gamma-herpesvirus using $\mathrm{MB}$ and visible light have been hitherto performed. In this work, we demonstrated that the infectivity of photoinactivated MHV-68 in BHK-21 cells strongly decreased; however, the virus remained infectious after a 120-s-long exposure to visible light in the presence of MB. We confirmed that infection of MRC-5 and NIH$3 \mathrm{~T} 3$ cells with photoinactivated MHV-68 was nonproductive as no infectious virus was produced by these cells. In cells that overcame crisis and could be subsequently passaged, MHV-68 DNA and virus antigen were detected and such a nonproductive infection resulted in the appearance of a morphologically transformed phenotype in cells. Two stable transformed cell lines of human and mouse cell origin were derived and demonstrated to contain both the viral DNA and the antigen. We demonstrat- ed that the transformed MRC-5 and NIH-3T3 cell lines remained stable until the 10th and the 8th passage, respectively. We observed that treatment of MHV-68 infection with $\mathrm{MB}$ exposed to visible light can result in nonproductive infection and the transformation of cells. The transforming ability of photoinactivated MHV-68 seems to be similar to that of MHV-68 exposed to UV light [27]. Thus, MHV-68 appears to be the first gamma-herpesvirus for which photoinactivation has been demonstrated to cause the acquisition of a transforming phenotype by infected cells.

In subsequent experiments, we focused on the effect of photoinactivation on latent infection typically occurring after the clearance of acute infection with herpesviruses, including MHV-68, in the host. To date, no reliable in vitro model exists to investigate the molecular mechanisms involved in controlling herpesvirus latency or virus reactivation during recurrent infection caused by herpesviruses. Few systems have been developed in which herpesvirus is retained in a nonreplicating state known as quiescence. Quiescent infection of cell cultures may provide an important and amenable means of studying the molecular mechanisms that mimic herpesvirus latency in vivo. Such in vitro models can be established at supraoptimal temperatures [41-43] or in the presence of inhibitors of DNA synthesis [34]. Here, we established quiescent infection of MHV-68 in MRC-5 and NIH-3T3 cells by infection with a low dose of virus $(0.01 \mathrm{PFU} / \mathrm{mL})$, cultivation in the presence of PAA, and a temperature shift from the usual 37 to $41{ }^{\circ} \mathrm{C}$. Next, cells were photoinactivated by a procedure previously described, enabling the induction of transformation of the cells infected with treated virus. First, we observed that photoinactivated MRC-5 and NIH-3T3 cells quiescently infected with nontreated virus acquired the transformed phenotype. However, the CPE was observed relatively early, after $4-5$ passages, before the cells degenerated. Next, when human IFN- $\alpha$ and mouse IFN- $\beta$ were added to the media of quiescently infected cells during the photoinactivating procedure, we obtained cells which demonstrated a transformed phenotype associated with visible disintegration of actin filaments. The morphology of cells of both types resembled the morphology of those obtained after nonproductive infection with photoinactivated MHV-68. Based on knowledge that IFN suppresses the reactivation of quiescent herpesvirus we used IFN to activate/accelerate the transformation of infected cells. However, the mechanism of this action is at present not fully understood. This phenomenon must be studied in future in more detail. Moreover, 2 stable transformed cell lines
66

Intervirology 2017;60:61-68

DOI: $10.1159 / 000479373$
Mrázová/Kúdelová/Smolinská/Nováková/ Šupolíková/Vrbová/Golais 
were established in which the presence of both viral DNA and the antigen was confirmed. We demonstrated that both transformed cell lines derived from photoinactivated cells quiescently infected with untreated MHV-68 remained stable until the 7th passage. Notably, nonphotoinactivated, quiescently infected cells (used as a control) cultured in the presence of IFNs did not demonstrate changes in their morphology. The only difference observed was the prolonged duration of quiescent infection, wherein CPE in cells was observed approximately 48-72 $\mathrm{h}$ later (following the removal of PAA and temperature shift).

Taken together, our results demonstrate that we prepared transformed MRC-5 and NIH-3T3 cell lines derived from the corresponding normal cell lines infected with photoinactivated MHV-68 as well as from photoinactivated MHV-68-infected quiescent cells. We demonstrated that photodynamic treatment of MHV-68 may lead, under some circumstances, to the transformation of cells that are nonproductively or latently infected with the virus. Although we cannot conclusively claim that PDT of recurrent herpes may be oncogenic, considering the results of this study on gamma-herpesvirus-infected cells, the possibility should be ruled out or confirmed in animal models of herpetic latency.

\section{Acknowledgements}

This work was supported by the Slovak Research and Development Agency (No. APVV-0621/12 and 15-0347) and the joint grant agency of the Slovak Ministry of Education and Slovak Academy of Sciences VEGA (No. 2/0087/17 and 1/0628/15). The authors also thank Prof. Koszinowski who provided us with the MHV-68 BAC.

\section{Disclosure Statement}

The authors declare that they have no conflicts of interest.

\section{References}

1 Hamblin MR, Hasan T: Photodynamic therapy: a new antimicrobial approach to infectious disease? Photoch Photobio Sci 2004;3: 436-450.

2 O’Riordan K, Akilov OE, Hasan T: The potential for photodynamic therapy in the treatment of localized infections. Photodiagn Photodyn Ther 2005;2:247-262.

3 Sudhakara RR, Kotha R, Tatapudi R, Gudapati S, Sai Madhavai N, Sai Kiran C: Photodynamic therapy in oral diseases. Int J Biol Med Res 2012;3:1875-1883.

4 Wainwright M: Local treatment of viral disease using photodynamic therapy. Int J Antimicrob Agents 2003;21:510-520.

5 Floyd RA, Schneider JE, Dittmer DP: Methylene blue photoinactivation of RNA viruses. Antiviral Res 2004;61:141-151.

6 Costa L, Faustino MA, Neves MG, Cunha A, Almeida A: Photodynamic inactivation of mammalian viruses and bacteriophages. Viruses 2012;4:1034-1047.

7 Yen GSL, Simon EH: Photosensitization of herpes simplex virus type 1 with neutral red. J Gen Virol 1978;41:273-281.

8 Schnipper LE, Lewin AA, Swartz M, Crumpacker CS: Mechanisms of photodynamic inactivation of herpes simplex viruses: comparison between methylene blue, light plus electricity, and hematoporphyrin plus light. J Clin Invest 1980;65:432-438.

9 Badylak JA, Scherba G, Gustafson DP: Photodynamic inactivation of pseudorabies virus with methylene blue dye, light and electricity. J Clin Microbiol 1983;17:374-376.
10 Müller-Breitkreutz K, Mohr H: Infection cycle of herpes viruses after photodynamic treatment with methylene blue and light. Beitr Infusionsther Transfusionsmed 1997; 34:37-42.

11 Kelleher JJ, Varani J: Photoinactivation of latent herpes simplex virus in rabbit kidney cells. Antimicrob Agents Chemother 1976;10: 229-233.

12 Latief MA, Chikama T, Ko JA, Kiuchi Y, Sakaguchi $\mathrm{T}$, Obama A: Inactivation of acyclovir-sensitive and -resistant strains of Herpes simplex virus type 1 in vitro by photodynamic antimicrobial chemotherapy. Mol Vis 2015; 21:532-537.

13 Felber TD, Smith EB, Knox JM, Wallis C, Melnick JL: Photodynamic inactivation of herpes simplex: report of a clinical trial. JAMA 1973;223:289-292.

14 Roome AP, Tinkler AE, Hilton AL, Montefiore DG, Waller D: Neutral red with photoinactivation in the treatment of herpes genitalis. Br J Vener Dis 1975;51:130-133.

15 Myers MG, Oxman MN, Clark JF, Arndt KA: Failure of neutral-red photodynamic inactivation in recurrent herpes simplex virus infections. N Engl J Med 1975;293:945-949.

16 Myers MG, Oxman MN, Clark JE, Arndt KA: Photodynamic inactivation in recurrent infections with herpes simplex virus. J Infect Dis 1976;133:145-150.

17 Marotti J, Aranha AC, de Paula Eduardo C, Ribeiro MS: Photodynamic therapy can be effective as a treatment for herpes simplex labialis. Photomed Laser Surg 2009;27:357363.
18 Marotti J, Sperandio FF, Fregnani ER, Aranha AC, de Freitas PM, de Paula Eduardo C: High intensity laser and photodynamic therapy as a treatment for recurrent herpes labialis. Photomed Laser Surg 2010;28:439-444.

19 Tardivo JP, Wainwright M, Baptista MS: Local clinical phototreatment of herpes infection in Sao Paulo. Photodiagnosis Photodyn Ther 2012;9:118-121.

20 Ramalho KM, Rocha RG, Correa-Aranha AC, de Barros Cunha SR, Simoes A, Campos L, de Paula Eduardo C: Treatment of herpes simplex labialis in macule and vesicle phases with photodynamic therapy: report of two cases. Photodiagnosis Photodyn Ther 2015;12:321323.

21 Li JLH, Rapp F: Oncogenic transformation of mammalian cells in vitro by proflavine-photoinactivated herpes simplex virus type 2 . Cancer Lett 1975;1:319-325.

22 Li JLH, Jerkofsky MA, Rapp F: Demonstration of oncogenic potential of mammalian cells transformed by DNA-containing viruses following photodynamic inactivation. Int J Cancer 1975;15:190-202.

23 Kucera LS, Gudson JP, Edwards I, Herbst G: Oncogenic transformation of rat embryo fibroblasts with photoinactivated herpes simplex virus: rapid in vitro cloning of transformed cells. J Gen Virol 1977;35:473-485.

24 Duff R, Rapp F: Oncogenic transformation of hamster embryo cells after exposure to inactivated herpes simplex virus type 1 . J Virol 1973;12:209-217.
Transformation by Photoinactivated Herpesvirus
Intervirology 2017;60:61-68 DOI: $10.1159 / 000479373$ 
25 Duff R, Rapp F: Quantitative assay for transformation of $3 \mathrm{~T} 3$ cells by herpes simplex virus type 2. J Virol 1975;15:490-496.

26 Rapp F, Reed C: Experimental evidence for the oncogenic potential of herpes simplex virus. Cancer Res 1976;36:800-806.

27 Mrázová V, Betáková T, Kúdelová $M$, Šupolíková M, Lachová V, Lapuníková B, Golais F: Murine gammaherpesvirus (MHV-68) transforms cultured cells in vitro. Intervirology 2015;58:69-72.

28 Simas JP, Efstathiou S: Murine gammaherpesvirus 68: a model for the study of gammaherpesvirus pathogenesis. Trends Microbiol 1998;6:276-282.

29 Stewart JP: Of mice and men: murine gammaherpesvirus 68 as a model. EBV Rep 1999; 6:31-35.

30 Barton E, Mandal P, Speck SH: Pathogenesis and host control of gammaherpesviruses: lessons from the mouse. Annu Rev Immunol 2011;29:351-397.

31 Čipková-Jarčušková J, Chalupková A, Hrabovská Z, Wágnerová M, Mistríková J: Biological and pathogenic characterization of different isolates of murine gammaherpesvirus 68 (MHV-68) in the context of study of human oncogenic gammaherpesviruses. Acta Virol 2013;57:105-112.

32 Mistríková J, Rašlová $H$, Mrmusová M, Kúdelová M: A murine gammaherpesvirus-review. Acta Virol 2000;44:211-226.
33 Nash AA, Dutia BM, Stewart JP, Davison AJ: Natural history of murine gammaherpesvirus infection. Philos Trans R Soc Lond B Biol Sci 2001;356:569-579.

34 Colberg-Poley AM, Isom H, Rapp F: Experimental HSV latency using phosphonoacetic acid. Exp Biol Med 1979;162:235-237.

35 Mačáková K, Matis J, Režuchová I, Kúdela O, Rašlová $\mathrm{H}$, Kúdelová $\mathrm{M}$ : Murine gammaherpesvirus (MHV) M7 gene encoding glycoprotein 150 (gp150): difference in the sequence between 72 and 68 strains. Virus Genes 2003; 26:89-95.

36 Rašlová H, Berebbi M, Rajčáni J, Sarasin A, Matis J, et al: Susceptibility of mouse mammary glands to murine gammaherpesvirus 72 (MHV-72) infection: evidence of MHV-72 transmission via breast milk. Microb Pathog 2001;31:47-58.

37 Kúdelová $M$, Belvončíková $\mathrm{P}$, Vrbová $\mathrm{M}$, Kovalová A, Štibrániová I, Kocáková P, Slovák M, Špitalská E, Lapuníková B, Matúšková R, Šupolíková M: Detection of murine herpesvirus 68 (MHV-68) in Dermacentor reticulatus ticks. Microb Ecol 2015;70: 785-794.

38 Chang TW, Fiumara N, Weinstein L: Genital herpes: treatment with methylene blue and light exposure. Int J Dermatol 1975;14:69-71.
39 Bockstahler LE, Coohill TP, Hellman KB, Lytle CD, Roberts JE: Photodynamic therapy for herpes simplex: a critical review. Pharmacol Ther 1979;4:473-499.

40 Robinson RA, Henry BE, Duff RG, O'Callaghan DJ: Oncogenic transformation by equine herpesviruses (EHV) I: properties of hamster embryo cells transformed by ultraviolet-irradiated EHV-1. Virology 1980;101: 335-362.

41 Michútová M, Mrázová V, Kúdelová M, Smolinská M, Šupolíková M, Vrbová M, Betáková T, Golais F: Human herpes simplex viruses type 1 and 2 photoinactivated in the presence of methylene blue transform cultured cells in vitro. Acta Virol 2017;61:309.

42 Preston CM: Reactivation of expression from quiescent herpes simplex virus type 1 genomes in the absence of immediate-early protein ICP0. J Virol 2007;81:11781-11789.

43 McMahon R, Walsh D: Efficient quiescent infection of normal human diploid fibroblasts with wild-type herpes simplex virus type 1 . J Virol 2008;82:10218-10230.

44 Jurak I, Hackenberg M, Kim JY, Pesola JM, Everett RD, Preston CM, Wilson AC, Coen DM: Expression of herpes simplex virus $1 \mathrm{mi}$ croRNAs in cell culture models of quiescent and latent infection. J Virol 2014;88:23372339. 